\title{
Determinants of Employability of Young People Aged 15-29 in Burkina Faso
}

\author{
Sayouba OUEDRAOGO \\ Correspondence: Dr Sayouba OUEDRAOGO, Economics Department, University Ouaga 2, post box 02 BP 6089 \\ Ouaga 02, Ouagadougou, Burkina Faso.
}

\author{
Received: June 10, $2018 \quad$ Accepted: June 29, $2018 \quad$ Available online: July 16, 2018 \\ doi:10.11114/aef.v5i5.3450 URL: https://doi.org/10.11114/aef.v5i5.3450
}

\begin{abstract}
The purpose of the article is to identify and analyze the employability determinants of young people aged 15-29. A logit model was estimated using data from Phases 1 and 2 of the multisectoral survey conducted in 2014 by the National Institute of Statistics and Demography (INSD) of Burkina Faso. The female gender, rural environment, monogamy, large household, non-membership in an organization, low-paid jobs, and socio-professional category of parents in the formal and modern labor market have positive effects and high probabilities of youth employment. On the other hand, vocational and technical training and higher education offer less chance of employment. Beyond the fight against youth unemployment, decent jobs for young people are needed, and social inequalities should be reduced. Also, an integrative approach that takes into account economic, social, psychological and managerial approaches is essential in analyzing the determinants of employability.
\end{abstract}

Keywords: employability, determinants, unemployment

\section{Introducation}

Employability is an answer to the fight against unemployment of young people in developing countries. The atypical work, the segmentation of the labor market, and the changes of the employment relationship make it more difficult to find work for young people. The difficulty or impossibility of the adjustment of supply and demand in the labor market reflects the issue of the employability of job seekers (Weinert, Baukens, Bollerot, Pineschi-gapenne and walwei, 2001). The purpose of this article is to identify and analyze the determinants of youth employability.

Employability is a profile currently sought by employers. According to ILO (2004), it is the ability of an individual to find and keep a job, to progress at work, and to adapt to change throughout working life. Employability is an alternative to the traditional models of employment and the economic security of individuals (Vultur, 2012; Stéphany, 1998). Employability transcends the orthodox debates on employment through supply versus demand to offer solutions of a complex combination of multiple factors (McQuaid and Lindsay, 2005). In addition, employability allows the enterprise to develop a sustainable competitive advantage and career success of the employee (Béraud, 2006). Thus, it is imperative to determine the determinants of youth employability.

Youth unemployment increases the risk of living in poverty (ILO, 2016; OECD, 2015). In Burkina Faso, the unemployment rates are $8.6 \%$ for young people aged 15-25 and 7.8\% for the age group 24-34 compared to 6.6\% for the overall national level (INSD, 2015). The corollaries of unemployment are the development of illicit activities, such as drug trafficking and consumption, prostitution, cybercrime, and inter-community conflicts, and sometimes dangerous migration routes.

The persistence of youth unemployment defies any theoretical construction using the variables of a unilateral approach to break the movement of capital and the behavior of social agents in the labor market (Musette, 1998). A logit model integrating the multi-dimensionality of employability made it possible to estimate social, individual, and economic variables using data from Phases 1 and 2 of the multisectoral survey of the National Institute of Statistics and Demography (INSD) carried out in 2014. The female gender, rural environment, low-wage jobs, and, above all, the socio-professional category of parents in the formal sector are determining factors in young people's access to employment. On the other hand, the different levels of education in the educational system offer less chance of employment. In addition, social inequalities are reflected in employability. Inclusive and equitable development policies, the regulation of pay for jobs, and the development of human capital in response to the structural change in the 
economy would improve the employability of young people.

Youth employment is a priority in the various economic policies of developing countries (Richevaux, 2017). Economic growth has effects on employment, but it does not systematically imply a reduction in youth unemployment, especially in African countries (ILO, 2013). The fight against unemployment, in addition to economic theories and their implementation, requires the control of population growth, the adaptation of training for employment, and the creation of additional jobs (Lututala, 2012; Zerbo, 2014). The use of initial and continuing training leads to employability, leading to a job. Understanding the transition mechanisms from school to employment leads to identifying the determinants of youth employability. For most youth, entry into the workplace is a time of uncertainty and instability. Employers place a high value on education and qualifications as selection criteria for jobs (Coleman \& Husen, 1985).

Yet access to employment in developing countries is determined less by the educational system diploma than by the logic of human capital (Schultz, 1961; Mincer, 1958, 1974; Becker, 1964). The majority of young people, especially graduates, are unemployed or confined to precarious or temporary jobs (El Aoufi \& Bensaïd, 2005). Unlike the results found by Mazari, Meyer, Rouaud, Ryk, and Winnicki (2011), the diploma is not protection against unemployment. In addition, the informal economies of the developing countries are far from monetary production. The wage rate does not determine the marginal productivity of services (Magnier, 1998). This is the opposite of the theory of efficiency wages (Leibenstein, 1957; Yellen, 1984; Stiglitz, 1971; Shapiro \& Stiglitz, 1984; Akerlof, 1982). Job availability is determined more by the segment in which the individual is located, and wages are a function of the status of the work of the producers and the sector of activity (Doeringer \& Piore, 1971).

The globalized economic and labor market demands force the individual to adapt continuously to the job to remain employable both internally and externally (Morin, 2010). This adaptation is the substance of existence (Darwin, 1859) and evolutions in the world (Nelson and winter, 1982). Employability is hardly collective (Canadian Labor Force Development Board, 1994). It subordinates public policies to make the individual more responsible for his or her training and job (Bernier, 2011). It is the responsibility of the individual (Barret, Whelen and Sexton, 2001). The inequity of individual resources increases inequalities in access to employment for young people. However, the inefficiency of public subsidies in the area of job creation for young people must be avoided (Acemoglu, 1995). In the context of deep and accelerated labor market changes requiring flexicurity and permanent adjustment, employability is the epicenter of public employment policies for different marginalized groups, such as young people, women, and the long-term unemployed (Thijssen, 2000).

After the introduction, Section 2 presents the socio-economic situation of Burkina Faso in relation to youth employment in the labor market. The methodology, variables, nature, and source of data and descriptive statistics are described in Section 3. Section 4 is devoted to empirical results, while Section 5 discusses these results before the conclusion in the last section.

\section{Socio-Economic and Demographic Aspects of Burkina Faso}

The average annual growth rate of the Burkinabè population is $3.1 \%$. This population is predominantly female and rural. The rates of males and urbanization are respectively $94.7 \%$ and $22.7 \%$ (Table 1). The demographics in Burkina Faso is the result of a gradual decline in mortality and the maintenance of a high level of fertility. The average household size is 7.2 people. A rural household of 7.7 is larger than the average urban household size of 5.7.

Table 1. Relative population size by gender and residence location

\begin{tabular}{|c|c|c|c|c|}
\hline & & \multicolumn{2}{|c|}{$\operatorname{Sex}(\%)$} & \multirow[t]{2}{*}{ Total (\%) } \\
\hline & & Male & Female & \\
\hline National & & 48.628 & 51.372 & 100 \\
\hline & $\begin{array}{l}\text { Urban } \\
\text { Rural }\end{array}$ & $\begin{array}{l}49.158 \\
48.473\end{array}$ & $\begin{array}{l}50.842 \\
51.527\end{array}$ & $\begin{array}{l}100 \\
100\end{array}$ \\
\hline
\end{tabular}

Source: INSD, 2014

Nearly $70 \%$ of this population is under 25 years old. The average and median ages are 21.3 and 16 years of age. In rural areas, these metrics are 20.7 and 14 years, respectively, compared to 23.5 and 20 years in urban areas (Table 2). 
Table 2. Median and mean ages by gender and residence location

\begin{tabular}{|c|c|c|c|c|c|c|}
\hline & \multicolumn{4}{|c|}{ Sex } & \multirow{2}{*}{\multicolumn{2}{|c|}{ Together }} \\
\hline & \multicolumn{2}{|c|}{ Male } & \multicolumn{2}{|c|}{ Female } & & \\
\hline & Mean age & Median age & Mean age & Median age & Mean age & Median age \\
\hline $\begin{array}{l}\text { National } \\
\text { Residence }\end{array}$ & 20.7 & 14 & 21.9 & 17 & 21.3 & 16 \\
\hline Urban & 23.6 & 20 & 23.3 & 20 & 23.5 & 20 \\
\hline Rural & 19.9 & 13 & 21.4 & 16 & 20.7 & 14 \\
\hline
\end{tabular}

$\mathrm{NB}$ : the ages are in the past year

Source: INSD, 2014

The growth rate of the young population is estimated at $3.7 \%$ compared to $3.1 \%$ for the overall population (MJFPE, ADB, \& ILO, 2013). There is a high social demand of specific needs including education, health, and work. In terms of health, Burkina Faso has a maternal mortality rate of 341 per 100,000 live births, 81.6 per thousand for under-five mortality, 23.2\% for neonatal mortality, and 43\%o for infant mortality (EMD, 2015).

Malnutrition remains endemic with a prevalence of acute malnutrition of $7.6 \%$ and stunting of $27.3 \%$ (SMART, 2016). At the level of education, the gross preschool enrollment rate increased from 2\% to $4 \%$ between 2005 and 2014 . The primary school enrollment rate increased from $57 \%$ to $83.74 \%$. The rate of access to secondary education increased from $20 \%$ to $44.9 \%$ for the first cycle and from $5.6 \%$ to $13.18 \%$ for the second cycle over the same period. In technical and vocational education and training ratios rose from 172.4 to 125.2 students per 100,000 inhabitants between 2006 and 2014 and from 235.2 to 530 students per 100,000 inhabitants for higher education. This quantitative progress in schooling is hardly accompanied by the quality of education. Only $28 \%$ of students have the required math and reading skills at the end of the primary cycle. As for the literacy rate, it went from 23.6\% to 34.5\% between 2005 and 2014 and remains lower than the average rate in Sub-Saharan Africa of 71\% (INSD, 2007, 2009, 2010, 2015). In addition, the life expectancy at birth is 58.6 years, and the poverty rate is at 40.1\% (INSD, 2014). However, over the period 2003-2013, the average gross domestic product (GDP) growth rate was 6\%. In 2017, the growth rate of the real GDP is estimated at $6.7 \%$ against $5.9 \%$ in 2016 and $4 \%$ in 2015. This GDP growth is due to mining activity, the intensification of investment in construction, the dynamism of the market sector, and agriculture. However, despite the economic performance, job creation and the reduction of unemployment remain tentative. Unemployment rates are $7.1 \%, 6.4 \%$, and $6.6 \%$, respectively, at the urban, rural, and national levels (INSD, 2015).

Unemployment affects more young women and men, and it decreases with age. For the age group 15-24, at the national level, it is 8.6\%: $12.3 \%$ for females, and 5.3\% for males. For 25-34 year olds, unemployment affects $11.5 \%$ of females versus $4.0 \%$ of males and $7.8 \%$ of the total population. The unemployment rate of young people aged 15-24 is still 3 times higher among girls than among boys. By level of education, it is $12.7 \%$ for preschool, $5.9 \%$ for primary, $17 \%$ for lower secondary, $6 \%$ for upper secondary, $18.6 \%$ for upper secondary, and $11.4 \%$ for higher education (INSD, 2015). Thus, the educational system hardly reconciles knowledge to fight against unemployment. The high percentage of youth in the population raises the crucial issues of employability. Similarly, the lack of a career plan, especially in the private sector, makes it difficult to maintain employment and reduces the adaptability of workers. To promote youth employment, Burkina Faso established a ministry in charge of youth in 2006. The country has set up financial funds for projects and capacity building for young people. In addition, it organized the States General of Youth in 2017. This country voted in law no. $028-2008 / \mathrm{AN}$ on the labor code and a national employment policy in 2008. It adopted and implemented a national policy on a technical and vocational education and training program in 2008, a special job creation program for youth and women in 2012, a 2015-2024 National Youth Policy in 2015, a 2016 National Economic and Social Development Program 2020 in 2016, etc. In addition, research on the labor market and employment in Burkina Faso focuses on the causes of unemployment, the labor market and poverty, the labor market and credit market, active market policies of labor, economic growth, international trade and employment, and training and employment (Dialla, 2014; Lachaud, 2000; Zerbo, 2010, 2011, 2014, 2017).

The multiple measures of employability are based on the potential of the individual to respond to the labor market. Employability includes a contract for the transition from employment risk to employability risk. The economic, environmental, social, and human capital variables are crucial.

\section{Methodology}

Analysis of the determinants of employability of 15-29 year olds is done through variables relating to individual (personal), social, and economic characteristics. This section presents the model to be estimated, the variables, and the nature and source of the data as well as some descriptive statistics. 


\subsection{Model}

Employability has a qualitative dichotomous character. For each individual observed, he or she is either employed or unemployed. A logit model that is variable dependent and qualitative is used for the analysis. It is appropriate in the case of our study because the dependent variable takes the value of 0 or 1 . Youth employability considers individual $(C I)$, social $(C S)$, and economic $(E C)$ characteristics. The model is:

$$
\text { employ }=B_{i}(C I, C S, C E)+U_{i}
$$

The probability of the individual $i$ accessing a job $\left(Y_{i}=1\right)$ or not $\left(Y_{i}=0\right)$ is a logit dichotomous model to analyze the factors associated with employability.

The probability of being employed or not is:

The link function of the probability of being busy is:

$$
\pi\left(X_{i}\right) .
$$

$$
g\left(\pi\left(X_{i}\right)\right)
$$

The logit function is :

$$
G(X)=\log i t\left(\pi\left(X_{i}\right)\right)=\log _{e}\left(\pi\left(X_{i}\right) /\left(1-\pi\left(X_{i}\right)\right)\right) .
$$

Employability depends on a number of characteristics, and the model is:

$$
Y_{i}(X)=\alpha+\beta X_{i}+\mu_{i} .
$$

with $X_{i}$ the vector of individual, social, environmental and economic characteristics of the young $\mathrm{i} ; Y_{i}$ is the variable explained; $\beta$ the vector of the parameters to estimate; $\mu_{i}$ the vector of disturbances following a standard logistic law and $i \in[1 ; N]$.

The estimated probabilities are:

$$
\pi\left(X_{i}\right)=\exp \left(Y_{i}(X)\right) /\left[1+Y_{i}(X)\right] .
$$

They range from 0 to 1 . The ratio between the probability of being employed in a job and the probability of not being employed (odds) is:

The odds ratio is:

$$
\pi\left(X_{i}\right) /\left(1-\pi\left(X_{i}\right)\right)=\exp \left(Y_{i}\right) .
$$

$$
\frac{\pi\left(X_{i}+1\right) /\left[1-\pi\left(X_{i}+1\right)\right]}{\pi\left(X_{i}\right) /\left[1-X\left(X_{i}\right)\right]}=\exp (\beta)
$$

If the explanatory variable is continuous, the odds ratio is sometimes close to 1 , a difference of one unit $X$ being insufficient to significantly change the odds ratio. It is better to calculate the odds ratio for a modification of $\delta \beta$, so that:

\subsection{Variables}

$$
\frac{\pi\left(X_{i}+\delta\right) /\left[1-\pi\left(X_{i}+\delta\right)\right]}{\pi\left(X_{i}\right) /\left[1-X\left(X_{i}\right)\right]}=\exp (\delta \beta)
$$

The selected explanatory variables are those of individual, social, and economic characteristics. These include sociodemographic variables, such as age, gender, level of education or type of training, and health status. There are also environmental variables that include the place of residence, size of the household, and marital status. In addition, there are social capital variables, such as membership in an association and the socio-professional category of the parent act. Finally, economic variables relate to income categorized by class. Nevertheless, variables related to organizational factors, attitudes, and psychological dispositions are excluded due to the unavailability of the data. 
Table 3. The different variables

Variables

Meaning and Expected Effects

The dependent or explanatory variable is employability $\left(Y_{i}\right)$

Employ Employability takes the value of 1 if the individual has a job in the labor market and the value of 0 otherwise.

Independent or explanatory variables $\left(X_{i}\right)$

Sociodemographic variables (known as human capital) include age, gender, level of education or type of training, and health status

Age Age: The probability of being employed is a function of age (Galdo, 1991). Age increases the likelihood

of entering the labor market (formal and informal) rather than being unemployed (Adair, 2009).

Gender Gender: Participation in the labor market or access to employment is a source of inequality between individuals according to gender (male or female), and women are often victims of this discrimination. Employers give men the first choice of jobs (Strober and Chan, 1998). It takes the value of 1 when the individual is male (gender 1) and the value of 2 (gender 2) if the individual is female. The expected sign is negative for females. The male gender is the reference variable.

niinstruc Educational attainment: An individual with a relatively high level of education receives more job offers and is expected to move to a job faster than a less educated job seeker. A positive influence of the educational level variable on employability is expected. The values are assigned as 1 for non-educated (niinstruc 1), 2 for preschool and primary (niinstruc 2), 3 for upper secondary cycle (niinstruc 3 ), 4 for general secondary education (niinstruc 4), 5 for secondary education second professional technique (niinstruc 5), and 6 for higher education (niinstruc 6). The variable without level is the reference.

Esant Health status: Professional activity requires physical, mental, and psychological efforts. In addition, health influences the productivity of the employee. A healthy individual is expected to be productive. The effect of health on employability is related to the state of health, which takes the value of 1 if the individual has no handicap (Esant 1), 2 for one-armed person/handicapped motor (one-armed person) (Esant 2), 3 for those who have a hearing impairment (Esant 3), 4 for a motor visual impairment (Esant 4 ), and 5 for others (Esant 5). Being healthy with no disability is the reference.

Environmental variables refer to the context in which the individual is found, such as place of residence, household size, marital status (Mincer, 1974).

Sitmatr Marital status: It allows the understanding of the responsibilities and burdens to which the individual faces. A polygamist does not have the same employability risks as a young single or other person (Galdo, 1991). The marital status variable takes the value of 1 if the individual is a monogamous husband (sitmatri 1), 2 for a polygamous groom (sitmatri 2), 3 for a common-law union (sitmatri 3), 4 for single/never married (sitmatri 4), and 5 for divorced/separated (sitmatri 5). A positive influence of the variable on employability is expected for married and widowed. The reference is the monogamous married individual.

milieuresid The place of residence: The geographical space influences the employability of an individual. Urban areas are places where unemployment is generally high because of the population pressure. It takes the value of 1 for the urban environment (milieuresid 1) and 2 for rural areas (milieuresid 2). The urban environment is the reference category. The expected positive sign is for rural areas.

tailmenage The size of the household: It refers to the size of the family of origin in which the individual is born. Household size has an effect on the income and employability of the individual (Griliches and Mason, 1972). Regardless of the place of residence, the expected sign is positive for a large household members over.

Social capital variables are membership in an association and the socio-professional category of the parent.

CSP parent The socio-professional category of the parent: The family situation is assimilated to the standard of living and social capital and has a significant influence on employability (Griliches and Mason, 1972). It has a value of 1 for senior managers and engineers (CSP parent 1), 2 for middle managers and supervisors (CSP parent 2), 3 for administrative and junior administrative staff (CSP parent 3), 4 for blue-collar workers (CSP parent 4), 5 for laborers and domestic workers (CSP parent 5), 6 for employers (CSP parent 6), 7 for self-employed workers (CSP parent 7), 8 for partners (CSP parent 8), 9 for apprentices (CSP parent 9), and 10 for family workers (CSP parent 10). A household head that is well placed in the labor market will have relational contacts that will allow the individual to easily insert a child or protégé into the labor market through recommendations (Cohen, Mason, Kovner, Leavitt, Pilcini and sochalski., 1996). The reference category is that of parents who are senior managers and engineers.

APPsoc Membership of an association or organization: It is the ability of the young person to be in an organization or association that allows the individual to have a network of relationships constituting social capital. This allows the individual to have an open mind, collaborative techniques, and teamwork. The belonging of individuals to networks facilitates their professional integration. Information on job opportunities or access to employment is promoted by the relationship network. Membership in an association positively influences the employability of the individual. The value of 1 is assigned to membership and 2 otherwise. Being a member of an organization is the reference modality.

The economic variables concern the income categorized by class

crevenu Income: It is the amount (in CFA francs) that the young person's parent gets from a job. The information on the distribution of income in CFA francs is consistent with the data from the INSD survey (2014). It is 1 (income 1) for income in the range of 0 to $31,000,2$ (income 2) for income from 31,000 to 50,000, 3 


Variables Meaning and Expected Effects

(income 3) for 50,000 to 80,000, 4 (income 4) for the range 80,000 to 110,000, 5 (income 5) for 110,000 to $140,000,6$ (income 6), for 140,000 to 180,000 , and 7 (income 7 ) for 180,000 and over. High income categories have a positive influence on employability. The potential endogeneity of the income variable implies the use of the expected income (Njikam, Tchoffo, \& Mwaffo, 2005). In fact, the socio-professional category of parents influences the income of the young person. There may also be other unobserved variables affecting income. However, the database is limited. The non-existence of consumer or other expenses for the young person does not make it easy to have an income proxy. Nevertheless, in the model, the income variable has several modalities. Range category 0 to 31,000 is the reference category.

\subsection{Nature and Source of Data}

The database comes from the multi-sectorial continuous survey (EMC) conducted in 2014 by the National Institute of Statistics and Demography (INSD) in Burkina Faso, which collected information on the living conditions of households. The sounding technique used is that of a two-stage stratified sounding. Primary units or enumeration areas (EAs) of a total of 905 were derived with probabilities proportional to the number of households enumerated in the LFA; the second degree drew 12 households in each of the equal probability EAs.

For our article, the data come from EMC Phase 1 and Phase 2, which were conducted over the national territory of Burkina Faso. The two phases are complementary and make it possible to consider the different members of households. The survey was conducted with representative households from all social and economic sectors (employment, health, education, housing, business, property income and pensions, non-pension current transfers, food consumption, non-food household, agriculture, etc.).

In view of the new structure of the education system and labor legislation in Burkina Faso and the youth of the Burkinabè population, the study concerns the population aged 15-29. Our work exploits data on the characteristics of household and employment members aged 15-29. It excludes the inactive population among the working age population and considers only the active population (employed and unemployed). The sample consists of 4,225 observations. Tables 1, 2, 3, and 4 below present some descriptive statistics of the sample of the study.

\section{Results}

To judge the validity of the model, the collinearity tests of the explanatory variables, the global significance test, the sensitivity and specificity tests are analyzed.

\subsection{Collinearity Test of the Explanatory Variables}

The collinearity test of the different explanatory variables used is the Hotelling test and leads to the rejection of the collinearity hypothesis of the explanatory variables. As a result, the different variables can be introduced together without the risk of misleading regressions.

Table 4. Hotelling test results

\begin{tabular}{lr}
\hline T-squared & 1600.489 \\
\hline F-test statistic F (37.817) & 542.711 \\
$p>F(37.2817)$ & 0.000 \\
\hline
\end{tabular}

4.2 The Overall Significance Test of the Model

The Wald test shows that the model is globally significant $\left(p>\chi^{2}=0.000\right)$, and the joint null hypothesis of the coefficients is rejected.

\subsection{Model Adequation Test}

The Hosmer-Lemeshow test shows the overall fit of the model to the data is satisfactory. Indeed, the test of the hypothesis $\mathrm{H0}$ "there is a relation between the set of independent variables chosen and the dependent variable" against the alternative hypothesis H1 (that the relations are not those that are postulated) makes it possible to accept the null hypothesis with $p>\chi 2=0.9069>5 \%$. In other words, the evaluation of the concordance between the predicted and observed values of the observations grouped in deciles shows that the model is adequate for studying the determinants of employability. 
Table 5. Hosmer-Lemeshow test results

\begin{tabular}{lllllll}
\hline Group & Prob & Obs_1 & Exp_1 & 0bs_0 & Exp_0 & Total \\
\hline $\mathbf{1}$ & 0.0415 & 8 & 9.7 & 274 & 272.3 & 282 \\
$\mathbf{2}$ & 0.0488 & 16 & 13.1 & 267 & 269.9 & 283 \\
$\mathbf{3}$ & 0.0516 & 14 & 14.1 & 267 & 266.9 & 281 \\
$\mathbf{4}$ & 0.0552 & 15 & 15.1 & 267 & 266.9 & 282 \\
$\mathbf{5}$ & 0.0589 & 18 & 16.1 & 264 & 265.9 & 282 \\
$\mathbf{6}$ & 0.0630 & 20 & 17.1 & 261 & 263.9 & 281 \\
$\mathbf{7}$ & 0.0692 & 21 & 18.6 & 261 & 263.4 & 282 \\
$\mathbf{8}$ & 0.0813 & 16 & 20.8 & 265 & 260.2 & 281 \\
$\mathbf{9}$ & 0.5931 & 66 & 68.1 & 217 & 214.9 & 283 \\
$\mathbf{1 0}$ & 0.9899 & 200 & 201.4 & 80 & 78.6 & 280 \\
Hosmer-Lemeshow $\boldsymbol{\chi 2}(\mathbf{8})=\mathbf{3 . 4 0}$ & & & & \\
$\mathbf{p}>\boldsymbol{\chi 2}=\mathbf{0 . 9 0 6 9}$ & & & & & & \\
\hline
\end{tabular}

4.4 Good Prediction Test Through Sensitivity

The good prediction rate is $90.56 \%$, and the false prediction is $9.44 \%$. The level of predictivity of the model is therefore satisfactory.

Table 6. Sensitivity test results

\begin{tabular}{llr}
\hline Sensitivity & $\operatorname{Pr}(+\mid \mathbf{D})$ & $\mathbf{5 7 . 1 1 \%}$ \\
\hline Specificity & $\operatorname{Pr}(-\mid \sim \mathrm{D})$ & $96.00 \%$ \\
Positive predictive value & $\operatorname{Pr}(\mathrm{D} \mid+)$ & $69.88 \%$ \\
Negative predictive value & $\operatorname{Pr}(\sim \mathrm{D} \mid-)$ & $93.23 \%$ \\
False + rate for true $\sim \mathrm{D}$ & $\operatorname{Pr}(+\mid \sim \mathrm{D})$ & $4.00 \%$ \\
False - rate for true D & $\operatorname{Pr}(-\mid \mathrm{D})$ & $42.89 \%$ \\
False + rate for classified + & $\operatorname{Pr}(\sim \mathrm{D} \mid+)$ & $30.12 \%$ \\
False - rate for classified - & $\operatorname{Pr}(\mathrm{D} \mid-)$ & $6.77 \%$ \\
\hline Correctly classified 90.56\% & & \\
\hline
\end{tabular}

4.5 Test of the Discrimination Power of the Model

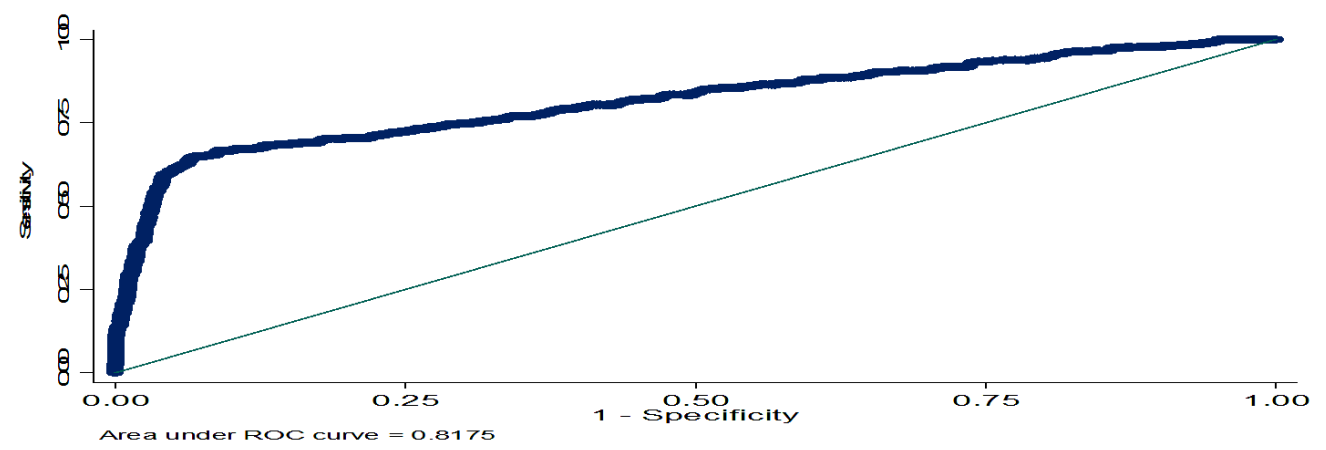

Figure 1. Discrimination test results

The value of the receiver operating characteristic (ROC) curve is $81.75 \%$ which is greater than $80 \%$. The model has excellent discrimination power. The test is better when the ROC curve approaches the upper left corner of the figure above.

The various tests above validate the model. Therefore, Table 11 presents the results of the estimation of marginal effects whose values can be interpreted, rather than the coefficients that only give the sense of the effect of the explanatory variable on the employability of the individual. 


\section{Discussion}

The influences of the explanatory variables on the explained variable are analyzed in relation to the marginal effects (odds).

Table 7. Marginal effects

\begin{tabular}{|c|c|}
\hline Variables & Odds ratio \\
\hline \multicolumn{2}{|c|}{ Sociodemographic variables/human capital } \\
\hline Age & $1.052(0.188)$ \\
\hline Female & $0.396 * *(0.029)$ \\
\hline Preschool and primary & $1.236(0.224)$ \\
\hline Secondary first cycle & $1.094(0.217)$ \\
\hline Secondary second general cycle & $1.282(0.411)$ \\
\hline Secondary second technical and professional cycle & $0.551(0.615)$ \\
\hline Higher education & $0.5708(0.375)$ \\
\hline one-armed person & $0.943(0.626)$ \\
\hline Visual & $0.396(0.487)$ \\
\hline Hearing & $2.457(2.859)$ \\
\hline Other & $2.811(3.021)$ \\
\hline \multicolumn{2}{|c|}{ Environmental variables } \\
\hline Polygamous married & $0.567(0.353)$ \\
\hline Free union & $0.824(0.480)$ \\
\hline Single & $0.828(0.149)$ \\
\hline Divorced/separated & $2.776(2.715)$ \\
\hline Rural environment & $0.921(0.154)$ \\
\hline Household size & $1.006 * * *(0.0100)$ \\
\hline \multicolumn{2}{|c|}{ Variables of social capital } \\
\hline Middle manager and supervisor & $4.359(5.849)$ \\
\hline Administrative and subordinate & $1.732(1.812)$ \\
\hline Workers & $0.436(0.419)$ \\
\hline Maneuver and domestic & $0.694(0.581)$ \\
\hline Boss and employer & $0.647 * *(0.079)$ \\
\hline Own account & $0.011 * * *(0.011)$ \\
\hline Family help & $0.019 * * *(0.184)$ \\
\hline Apprentice/trainee & $0.080 *(0.077)$ \\
\hline Non-member association & $1.212(0.346)$ \\
\hline \multicolumn{2}{|c|}{ Economic variables/employment income } \\
\hline Income: 31,000 to 50,000 & $0.959(0.410)$ \\
\hline Income: 50,001 to 80,000 & $4.816^{*}(2.986)$ \\
\hline Income: 800,001 to 110,000 & $0.337(0.325)$ \\
\hline Income: 110,001 to 140,000 & $1.738(0.881)$ \\
\hline Income: 140,001 to 180,000 & $0.841(0.809)$ \\
\hline Income: 180,001 to and over & $1.296(0.870)$ \\
\hline constante & $1.560(1.870)$ \\
\hline
\end{tabular}

NB: $* * *, * *, *$ : significant respectively at $1 \%, 5 \%$, and $10 \%$; standard deviation is in parentheses.

Sociodemographic variables or human capital were highlighted for access to work. The female gender has a positive and significant effect on employability. This result is consistent with those found by Njikam, Tchoffo, and Maffia (2005), Boutin (2010) in Cameroon, Zallé, Noufé, and Sandwidi (2014) in Burkina Faso, and Mamgain and Tiwari (2015) in India, but is contrary to the results of Van der Heijde and Van der Heijden (2006) in the Netherlands.

In recent years, there has been an active gender mainstreaming policy in employment promotion strategies for young people. The various professions most concerned by this policy are mechanics, welding, masonry, hairdressing, sewing, entrepreneurship, military, catering, executive secretary, security, etc. In addition, the majority of girls in this category have benefited from the implementation of new educational strategies promoting equality between girls and boys. The metamorphosis of the Burkinabè society regarding social burdens tends to gender equality in the labor market for young people. Strategies for promoting gender should be maintained and strengthened, while women's economic activities should be supported by funding and mentoring.

Age positively influences employability and is not significant. This result is contrary to the findings of Van der Heijden and Van der Heijde (2006), Ouédraogo (2017), and Zallé, Noufé, and Sandwidi (2014). The informal labor market and the persistence of socio-cultural burdens explain this situation. 
The level of education has a positive influence on the employability of young people aged 15-29. On the other hand, no variable is significant. This result is contrary to our expectations because of the reduced number of educated individuals at the levels of higher education, general secondary and postgraduate, secondary second cycle technical professional, and the educational option of Burkina Faso to privilege technical and vocational education. The employability of the vocational training students is contrary to the result found by Zallé, Noufé, and Sandwidi (2014) in Burkina Faso. These authors did not cover other levels of education or the entire national territory. The acquisition of a high level of education in technical and vocational, university, or higher education institutions increases the probability of being unemployed, hence the absence of working income. The financial profitability of educational investment may not be assured for young people at these levels of education. Young people who participate in the labor market are excluded from the school system.

As a result, they have a low level of education, if at all. Those who have had access to education are generally without experience in the labor market, making it difficult for them to access employment. The economy, heavily dominated by the informal and individual private sector, is weakly reliant on higher education levels compared to primary education for economic or cost reasons. In addition, educated people beyond primary education employ themselves with difficulty in an informal economy with little innovation. In the long run, a decline in the numbers of the educated could be induced in these types of higher education levels, resulting in the inefficiency of development strategies. The low competitiveness of the Burkinabè economy is justified by the low quality of human capital of the workforce. Youth employment access policies must consider the process of improving the economic bases for the implementation of learning outcomes and facilitate the self-employment of young people in high employability sectors.

The youth environment variables show that the rural home environment has a positive non-significant effect on the employability of the young person. This is contrary to the results of Ouédraogo (2017), Gobillon and Selod (2004), and Njikam, Tchoffo, and Mwaffo (2005). The low capacity to create jobs in relation to urban development, the rural exodus, and the high concentration of potential workers, especially graduates, in cities increases unemployment in urban areas (Kuépié and Christophe, 2010; Lachaud, 1998). The informal economy induces spatial segregation, which increases inequalities in employability. In addition, entry into the labor market segment of the informal sector employing young people hardly lends itself to the distinction between urban and rural.

Marital status positively influences employability. This result is contrary to those of Othmane (2011) and Feldman and Bolino (1998) and in line with the conclusions of Zallé, Noufé, and Sandwidi (2014). The married, polygamous, common-law, and single (never married) marriage categories were $43.352 \%, 17.527 \%$, and $17.614 \%$, respectively, less likely to be employed than the married monogamous category. Polygamy and common-law are officially less recognized by the public administration yet admitted by society, which appreciates a single young person less. Monogamous newlyweds could benefit from informal support for access to employment through the family network or the transformation of society with the development of monogamy and administrative norms. On the other hand, divorced/separated/widowed young people have a $177.643 \%$ increased chance of employment. Family responsibilities exert social pressure. In addition, the search for autonomy and the constraints of society contribute to the development of the consequent strategy of the young people of this marital situation to maximize their chances of employment. The majority of these jobs is precarious or is in the informal economy. Household size positively influences the employment of the 15-29 year old. This result is consistent with those of Zallé, Noufé, and Sandwidi (2014), Njikam, Tchoffo, and Mwaffo (2005) and Ouédraogo (2017). A large household increases the youth's chance of being employed by 0.6\%. A multi-person household exerts social pressure on the young person to seek employment to enter the labor market (Griliches and Mason, 1972). Modest household resources force the young person to contribute to the functioning of the household. Thus, young people from modest families are most often found in precarious jobs. Their employability is more on the secondary job market or peripheral market. This market is characterized by low wages, low profits, poor working conditions, low promotion chances, and high turnover (Doeringer and Piore, 1971).

A larger household increases young people's employment in low-paying, low-wage jobs, and increases poverty. Yet $52.096 \%$ of Burkinabè households are large or extended households (INSD, 2015). Responses to extended households could be the rigorous implementation of population, health, and economic policies to control population growth, improve health conditions, and, above all, ensure wellbeing. As for social capital variables, they show that the socio-professional category (CSP) of parents has a positive influence on the employment of young people. Those of middle management or supervisory and administrative or subordinate employees, respectively, have $335.914 \%$ and 73.23\% chance of being employed as children of senior executives and engineers. On the other hand, young people whose parents are laborers, domestic workers, employers, self-employed workers, caregivers, and apprentices have $56.485 \%, 30.635 \%, 33.393 \%, 98.917 \%, 98.106 \%$, and $92.176 \%$, respectively, less chance to be employed. The employability of young people whose parents are self-employed workers and family caregivers is significant at the level of $1 \%$. For young people with parents/employers and apprentices/trainees, their employability is significant at the 5\% and $10 \%$ levels, respectively. 
These results show that the great chance of employment of young people is also a function of the socio-occupational status of their parents in the formal administrative sector. Young parents/employers and apprentices have a significantly reduced chance of employment. In other words, social inequalities accentuate the inequalities of employment of young people aged 15 to 29. The socio-professional category of parents in the formal modern economic sector is more decisive in access to employment. Non-membership in an organization/association, such as associative life has a positive influence on employment. Yet the creation of a network of knowledge, relationships, and modes that facilitate research and access to employment (Seibert, Kraimer and Liden, 2001). The formal and informal network of relationships facilitates the flow of information from employment opportunities (McArdle, Watters, Briscoe and Hall, 2007). In other words, the community sector is an asset for access to employment. The result would indicate a weak adhesion of the youths to the associative movements. Theses associations don't answer their aspirations of the life. This would also explain the low participation rate in the country's various political elections through the political party channel. In addition, associative movements develop less strategies of access to the employment of the young people.

Finally, economic variables/monetary earnings indicate that class income has a positive influence on employment. Earnings in the ranges of 50,000 to $80,000,110,000$ to 140,000 , and 180,000 and over, respectively, have $31.816 \%$, $73.817 \%$, and $129.618 \%$ increased chance of employment than the 0 to 30,000 range. Income ranges 30,000 to 50,000 , 80,000 to 110,000 , and 140,000 to 180,000 for young people have less chance of employment, respectively, at $4.138 \%$, $66.345 \%$, and $15.926 \%$. The probability is significant at the $10 \%$ level for the range of 50,000 to 80,000. In other words, young people are more employable in the low income bracket and close to the guaranteed minimum wage (SMIG). Considering the loss of employment is linked to unemployment, this leads to accepting a job that pays less immediately. This is a strategy to combat unemployment through a form of acquisition of human and social capital in the workplace to create valuable experiences in the labor market. This result would explain the increase in precarious and poor jobs. Constraints lead to accepting poorly paid, low-productivity jobs to survive. Beyond unemployment, underemployment is a problem of the employability of young people and a consequence of household poverty. The fight against unemployment and precarious employment would boost economic activity in high productivity sectors using high quality skills and above all, a decent wage rate.

\section{Conclusion}

The purpose of this article was to identify and analyze the determinants of employability of young people aged 15-29 in Burkina Faso. To conduct the analysis, a logit dichotomous model of employability using variables related to human and social capital, family environment, and the summer economy were used. Estimates were made from the 2014 Multi-sectorial Continuous Survey (CEM) database of the National INSD in Burkina Faso. The results show that gender, socio-professional category of parents as home help, trainee/apprentice, low level of employment income, and weak human capital, such as the acquisition of preschool and primary education, have significant effects on the employability of a young person. Young people in large households, those with middle-level parents as supervisors, administrative, and subordinates, and those who are divorced/separated have a greater chance of employment. The economic sector of parents' socio-professional activity and income play a big role in the employment of young people. Social inequalities are reflected in the employment of 15-29 year olds. Promoting employment requires inclusive and equitable development policies, decent remuneration for work, the development of human capital in education, responding to the structural change in the economy, and the implementation of a social strategy to benefit those who are divorced or widowed. In addition, the effects of the socioprofessional category of parents are to be analyzed. Otherwise, psychological and managerial variables were not included in the study. This is a limitation for this paper. Thus, future research will focus on an integrative approach that takes into account economic, social, psychological and managerial approaches in analyzing the determinants of employability.

\section{Acknowledgements}

I firstly appreciate this journal for its kind repeated article invitation, particulary Nikki Gibbs for the invitation messages to soubmite my paper. In addition, I am very grateful an editor of this journal and anonymous reviewer for their constructive and spportive comments on this paper. Finally, I deeply thank all the Editors of this journal for their kind attention to my paper.

\section{References}

Acemoglu, D. (1995). Public policy in a model of long term unemployment. Economica, 62(246), 161-178. https://doi.org/10.2307/2554901

Adair, P. (2009). Economie non observée et emploi informel dans les pays de l'Union europeene. Revue Economique, 60, 1117 - 1153. https://doi.org/10.3917/reco.605.1117

Akerlof, G. (1982). Labor contracts as partial gift exchange. Quarterly Journal of Economics XCII, 543 - 569. https://doi.org/10.2307/1885099 
Barret, A., Whelan, C., \& Sexton, J. (2001). Employability and its relevance for the management of the life register. Economic and Social Research Institute (ESRI), Dublin, 1-74.

Becker, G. S. (1964). Human capital, a theorical and empirical analysis, with special reference to education. Colombia, New York: University Press .

Bernier, L. (2011). The 2008 economic crisis and the rebirth of public entreprises. CIRIEC, Dance \& Bernier.

Boutin, D. (2010). La transition des jeunes Camerounais vers le marché du travail . Groupe d'Economie du Développement de l'université Montesquieu Bordeaux IV, Handle RePEC: mon Cddtr. 152; Http://ged.u-bordeaux4.fr/ceddtr152.pdf.

Canadian Labour Force Development, B. (1994). Putting the piece together: Towards a coherent transition system for Canada. . Ottawa: canada Labor Force Development Board.

Cissé, M. (2005). Les déterminants du chômage au Sénégal : le rôle de l'éducation. Université Cheik Anta Diop: Dakar.

Cohen, S. S., Mason, D. J., Kovner, C., Leavitt, J. K., Puleini, J., \& Sochalski, J. (1996). Stages of nursing's political developement: Where we've been and we ought to go. Nursing outlook, 44(6). https://doi.org/10.1016/S0029-6554(96)80081-9

Coleman, J. (1990). Foundation of social theory. Cambridge: University Press.

Coleman, J., \& Husen, T. (1985). Devenir adiulte dans une société en mutation. Paris: O.C.D.E.

Dialla, B. (2014). La question de l'emploi des jeunes: une analyse du cas du Burkina Faso. Les cahiers du CEDIMES, 130 - 144.

Doeringer, P., \& Piore, M. (1971). Internal Labor Market and Manpower Analysis. Lexington: Health: Books,.

El Aoufi, N., \& Bensaîd, M. (20O5). Chômage et employabilité des jeunes au Maroc. Rabbat: University Mohammed V - agdol.

EMD. (2015). Rapport périodique du Burkina Faso établi en application de l'article 62 de la charte africaine des droits de l'homme et des peuples. Ouagadougou: Burkina Faso. http://www.archpr.org/files/sessions/57th/...reports/3...2015/burkina_faso_state_report_fra.p.

Feldman, D. C., \& Bolino, M. (1998). Moving on out: When are employees willing to follow their organization during corporate relocation? Journal of Organisational Behavior, 19(3), 275-288. https://doi.org/10.1002/(SICI)1099-1379(199805)19:3<275::AID-JOB840>3.0.CO;2-S

Galdo, R. (1991). Sortir du chômage: un parcours à handicaps. Economie et statistique, 53-66. https://doi.org/10.3406/estat.1991.5616

Griliches, Z., \& Mason, W. (1972). Education, income and ability. Journal of Political Economy, 80(3), 74-103. https://doi.org/10.1086/259988

ILO. (2004). Training for employment social inclusion productivity and employment. International Labour Conférence 88th session report, $V$. . Geneva.

ILO. (2013). Global Employment social outlook, trend for youth 2016. Geneva: ILO.

ILO. (2016). World Employment social outlook, Trends for Youth 2016. Geneva: ILO.

INSD. (2006). Recensement général de la population et de l'habitation (RGPH) . Ouagadougou: Ministère de l'Economie et des Finances.

INSD. (2007). Analyse de quelques résultats de l'enquête annuelle sur les conditions de vie des ménages en 2007, EA/QUIBB 2007. . Ouagadougou: Ministère de l'Economie et des Finances.

INSD. (2009). Analyse de quelques résultats de la phase principale de l'Enquête intégrale sur les conditions de vie des ménages (EICVM). Ouagadougou: Ministère de l'Economie et des Finances.

INSD. (2010). Enquête intégrale sur les conditions de vie des ménages (EICVM). Ouagadougou : Ministère de l'Economie et des Finances.

INSD. (2015). Enquête multisectorielle (EMC) sur emploi et chômage de janvier-mars 2014. Ouagadougou: Ministtère de l'Economie et des Finances.

Kuepie, M., \& Christophe, J. N. (2005). Education et marché du travail à Brazzaville et à Pointe Noire (Congo-Brazzaville). . Paris: DIAL, 2011EA, IDEP, 2005, 80.

Lachaud, J. (1998). Modélisation des déterminants de la pauvreté et marché du travail en Afrique: la cas du Burkina Faso. Bordeaux: Université Montesquieu-Bordeaux IV. 
Lachaud, J. P. (2000). Modélisation des déterminants de la pauvreté et marché du travail en Afrique: le cas du Burkina Faso. Louvain Economie Review, 66(3), 309-361.

Leibenstein, H. (1957). Economie backwardness and Economic growth. New york: John Wiley.

Lututala, B. M. (2012). Capacités nécessaires pour l'accès o l'emploi en Afrique subsaharienne. Rapport pour le projet Innovative Secondary Education for Skills Enhancement (ISESE ${ }^{\circ}$ et Results for Development Institue (R4D) avec le soutien de la Fondation Rockefeller.

Magnier, A. (1998). Les limites de la théorie des salaires d'efficience. Laboratoire d'analyse et de techniques économiques (LATEC), Graph réf.:26 ref. hal-01526989.

Mamgain, P., \& Tiwari, R. (2015). Youth India: Challenge of employment and employability . Giri institute of Development Studies .

Mazari, Z., Meyer, V. R., Ryk, F., \& Winnicki, P. (2011). Le diplôme: un atout gagnant pour les jeunes face à la crise. Céreq Bref n²83. http://www.cereq/fr/publications/Cereq-Bref/Le-diplome-un-atout-gagnant-pour-les-jeunes-face-a-la-crise

McArdle, S., Watters, L., Briscoe, J., \& Hall, D. (2007). Employability during Unemployment : Adaptability, career identity and human and social capital. Journal of Vocational Behavior, 71, 247-264. https://doi.org/10.1016/j.jvb.2007.06.003

McQuaid, R., \& Lindsay, C. (2005). The concept of employability . Urban Studies, 42(2), 197-219. https://doi.org/10.1080/0042098042000316100

Mincer, J. (1958). Investment in human capital and personnal income distribution. Journal of Political Economy, 66, 281-302. https://doi.org/10.1086/258055

Mincer, J. (1974). Schooling, Experience and Earnings. Columbia: University Press, New-york.

MJFPE, BAD, \& BIT. (2013). Rapport sur la cartographie et diagnostic de l'emploi des jeunes au Burkina Faso. Ouagadougou: Ministère de la Jeunesse, de la Formation Professionnelle et de l'Emploi .

Morin, Y. (2010). Que signifie intégrer en pédagogie. Revue Pédagogique Collégiale, 23(2).

Musette, M. S. (1998). Les théories économiques à l'épreuve du chômage. Cahiers du CREAD, 45, 101-125.

Nelson, R., \& Winter, S. (1982). An evolutionnary theory of economic change . Journal of economic litterature, 33(1), 48-90.

Njikam, G., Tchoffo, L. M., \& Mwaffo, F. V. (2005). Caractéristiques et déterminants de l'emploi des jeunes au Cameroun. unités Politique de l'emploi/Département de la stratégie en matière d'emploi, 91.

OCDE. (2015). Resserrer les liens avec les diasporas: panorama des compétences des migrants . Publication conjointe AFD et OCDE.

Othmane, J. (2011). L'employabilité: définition, création d'une échelle de mesure et contribution à l'étude des déterminants. Lyon: Thèse de Doctorat de l'Université jean Moulin, 456 p. .

Ouédraogo, A. (2017). Etude comparée des déterminants de l'emploi des jeunes et des jeunes et des adultes au Burkina Faso. Les Cahiers du CEDIMES, 31-44.

Richevaux, M. (2017). lutter contre le chômage. Les cahiers du CEDIMES, 11(2), 7-11.

Schultz, W. (1961). Investment in Human Capital. Thee American Economic Review, II(1), 1-17.

Schyns, B. (2006). Employability en individuele ontwikkeling op het werk= Employability and employee development at work. Gedrag en organisatie, 19, 53-68.

Seibert, S. E., Kraimer, M. L., \& Liden, R. C. (2001). A Social Capital Theory of Career Success. Academy of Management journal, 44, 219-237.

Shapiro, C., \& Stiglitz, J. (1984). Equilibrium unemployment as a worker discipline device. American Economic 74, 433-444.

SMART. (2016). Enquête nutritionnelle nationale. Ouagadougou: Ministère de la Santé, p.53. https://www.humanitarianresponse.info/files/.../smart_2016.pdf.

Stephany, E. (1998). Analyse de l'impact d'un financement par capital risque sur l'organisation et le management de la PME. Dans O. Torres, PME de nouvelles approches, "Recherche en Gestion" (pp. 105-120). Paris: Economia Co.

Stidlitz, J. E. (1971). Perfect and Imperfect Capital markets. New Orleans: Econometric Society Meeting. 
Strober, M., \& Chan, A. M. (1998). husbands, wives, and housework: graduates of stanford and Toyo universities. Feminist Economics 4(3), 97-127. https://doi.org/10.1080/135457098338329

Thijssen, J. (2000). Employability in het brandpunt. Aanzet tot verheldering van cen diffuus fenomeen. Tijdschrift Voor $H R M, 1,7-34$.

Van der Heijde, C., \& Van der heijden, B. (2006). A competence based and multidimensional operationalization and measurement of employability. Human Resource Management, 45(3), 449-476. https://doi.org/10.1002/hrm.20119

Vultur, M. (2012). Formation et employabilité. Dans C. Bernier, Regard critique sur l'évolution des politiques de formation de la main d'oeuvre au Quebec (p. 195). Quebec: Les presses de l'université Laval.

Weinert, P., Baukens, M., Bollerot, P., Pineschi, G. M., \& Walwei, V. (2001). L'employabilité de la théorie à la pratique. Dans P. L. SA, Employabilité . Bern: Editions scientifiques europeennes.

Yellen, J. (1984). Efficiency wage models of unemployment. American Economic Review, 74(2), 200-205.

Zallé, O., Tiatité, N., Sandwidi, H., \& Kéré, S. (2014). La formation professionnelle et employabilité dans les milieux urbains et l'exemple de la ville de Ouagadougou. Journal of Economic Litterature (JEL).

Zerbo, A. (2010). Les politiques du marché du travail et l'emploi au Burkina Faso. Génève: Bureau International du Travail, Unités de recherchges et analyses dur l'emploi, Département économique et marchés du travail.

Zerbo, A. (2011). Quels intinéraires d'intégration au commerce mondial pour plus d'emplois décents. Bordeaux: Université Montesquieu, Bordeaux IV: Groupe d'économie du développement, LARE-EFI, DT/166/2011.

Zerbo, A. (2014). Impact de l'inadéquation formation-emploi sur le chômage: un modèle d'analyse. Bordeaux: Université Montesquieu Bordeaux IV. Groupe d'économie du développement, LARE-EFI, DT/173/2014, 3-18.

Zerbo, A. (2017). Croissance économique et chômage: Les fondelents de la loi d'Okum et le modèle IS-LM-LO. Bordeaux: Université Montesquieu Bordeaux IV, Groupe d'économie du développement, LARE-EFI, DT/176/2017.

\section{Copyrights}

Copyright for this article is retained by the author(s), with first publication rights granted to the journal.

This is an open-access article distributed under the terms and conditions of the Creative Commons Attribution license which permits unrestricted use, distribution, and reproduction in any medium, provided the original work is properly cited. 